„Bohemistyka” 2020, nr 2, ISSN 1642-9893

Marie ČECHOVÁ

Univerzita Karlova

\section{Čeština jako jazyk nemateřský}

Čtenáři „Bohemistyky” se dostává do ruky recenze nové knihy jemu známého, kmenového autora tohoto časopisu, Milana Hrdličky, bohemisty soustředěného pře- devším, ale nejen na češtinu jako jazyk cizí a druhý, totiž nemateřský. Hlavními periodiky, jež zveřejňují Hrdličkovy studie, jsou dva lingvodidaktické časopisy zaměřené na češtinu, „Bohemistyka” a „Český jazyk a literatura”. Časopis „Bohemistyka” publikuje vcelku pravidelně Hrdličkovy postřehy o různých jazykových jevech, „Český jazyk a literatura” hlavně jeho úvahy o výuce mluvnickým jevưm, kritické analýzy výukových postupů...

Milan Hrdlička zdařile spojuje znalosti lingvistické teorie se svou lingvodidaktickou orientací, což je prvotním předpokladem, aby vzniklo kvalitní dílo z oboru teorie a praxe vyučování jazyku, ale to je zároveň to, co mnohým didaktikům chybí (doklady najdeme i v Hrdličkových analýzách různých statí a učebnic podaných v této publikaci).

Posuzovaná monografie ${ }^{1}$ je sestavena $\mathrm{z}$ autorových vybraných článků a statí publikovaných $\mathrm{v}$ obou jmenovaných periodikách, ale i jinde $\mathrm{v}$ zahraničí (od roku 2010 do roku 2018). Je př́nosné, že v ní čtenář nalezne i texty obtížně dostupné, vydané v Bulharsku nebo v Jižní Koreji. Milan Hrdlička v knize zhodnotil své dosavadní celoživotní zkušenosti s výukou cizinců jak v Praze, tak z opakovaných dlouhodobých zahraničních pobytů (naposledy v Koreji).

Práce je určena široké obci filologů, zejména těm se zájmem o lingvistickou bohemistiku a lingvodidaktiku, o češtinu jako jazyk cizí, druhý, ale i mateřský (pojatou z nadhledu, jak ji vnímá nerodilý mluvčí), ale může ji s prospěchem studovat i nelingvista se zájmem o jazyk a řeč.

Monografie se skládá ze tří základních oddílů $(\mathrm{A}, \mathrm{B}, \mathrm{C})$. První přináší výběr sedmi př́spěvků uveřejněných $\mathrm{v}$ časopise „Český jazyk a literatura”, s pestrým spektrem aktuálních otázek: prezentace a popis slovesného vidu, českých prepozic, pojednání o výuce naší mateřštiny $\mathrm{v}$ zahraničí, o principech výběru mluvnického učiva, o problematice užívání otázky ve vyučování; zvlášt' přínosná je kapitola o kompenzačních strategiích, totiž o tom, jak nahrazovat nedostatečné nebo absentující jazykové znalosti v komunikaci (navrhované postupy mohou být využitelné i ve výuce mateřštiny). Vcelku lze říci, že M. Hrdlička je odpůrcem metod učit jazyku bez gramatiky, soustředí se na to, jak gramatiku účelně zvládat, se zřetelem ke komunikačním potřebám mluvčích různé úrovně.

Druhý oddíl přináší šest př́ispěvků otištěných v polském časopise „Bohemistyka”. Jde převážně o jazykové, resp. bohemistické zajímavosti, kupř. o nahrazováni jmenné koncovky genitivu lokálem (Jedem do Čechách), o substantivizovaných adjektivech, o problémech s koncovkami posesivních adjektiv apod., tedy o konkrétní jazykové/řečové jevy, které mohou cizince, ale nejen je, zajímat a které jsou pro ně významné.

${ }^{1}$ Milan Hrdlička, Kapitoly o češtině jako jazyku nemateřském, Praha: Karolinum, 2019. ISBN 978-80-2464-297-0. 
Třetí oddíl, Varia, představující těžiště monografie, přináší výběr 10 příspěvků $\mathrm{z}$ různých konferenčních sborníků i dalších odborných časopisů. Také v těchto kapitolách se probírají aktuální témata, kupř. různé aspekty české deklinace (příčiny její obtížnosti, zvláště pro cizince, variantnost formálního tvarosloví - správně se odlišuje varianta od variety), uplatnění principu analogie ve výuce češtiny, problémy s českými prepozicemi, s číslovkami a s číselnými výrazy, předkládají se i vyvracejí různé názory na tzv. jazykovou správnost, na chybu atd. Za velmi př́nosnou - zvláště pro učitele češtiny cizince - považuji kapitolu (3) o meziválečné a (hlavně) poválečné diskusi o obecné češtině, o jejím funkčním a regionálním uplatnění a ve vztahu k češtině spisovné.

Při studiu knihy může čtenáře právem napadnout, že by bývalo vhodné jiné třídění knihy, a to podle tematických okruhů, tedy přiřazovat $\mathrm{k}$ sobě př́spěvky podle jejich tematické blízkosti, místo řazení oddílů podle toho, $\mathrm{v}$ kterém periodiku byly př́íspěvky publikovány.

Oceňuji, že autor u každé studie uvádí původní pramen, v němž čtenář, pokud chce, prvotní text najde, mj. se také může orientovat v chronologii př́ispěvků. $\mathrm{Ku}$ prospěchu věci autor v monografii sjednotil zápis bibliografických údajů; různá periodika se totiž v požadavcích na ně zčásti odlišují, a tak autor bohatou odkazovou literaturu (uvedena je za každou kapitolou, tedy ke každému tematickému okruhu) upravoval.

Už z naznačeného obsahu je patrno, že se čtenáŕi předkládá bohatá škála zajímavých problémů jak systémových, tak komunikačních, na předním místě lingvodidaktických a že se zabíhá i do oblasti jazykové a řečové kultury. Všechny tři oddíly kromě jmenovaných tematických okruhů obsahují i otázky obecného rázu.

Protože jednotlivé kapitoly odpovídají jednotlivým časopiseckým př́spěvkům, které jako osamostatněné oprávněně s ohledem na celistvost textu některá fakta a výklady opakovaly, $\mathrm{v}$ př́ípadě monografie by bylo bývalo možné míru opakování výkladů a př́kladového materiálu snížit.

K této poznámce přičleňuji dotaz: Proč mezi dvaceti třemi kapitolami je jedna, a to nejrozsáhlejší (15 stran), psaná anglicky? Ostatní kapitoly mají rozsah menší (pod 10 stran), až na jednu (o 12 stranách), a to zásadní (o evropanství a světovosti češtiny). Jmenovaná anglicky psaná kapitola Charakteristics and Usage of Czech Prepositions shrnuje a do jisté míry opakuje výsledky soustavného Hrdličkova zájmu o předložky, významné nositelky vztahů ve větě - jejich základní funkci (spolu s adverbii a se spojkami) si mnozí vyučující (nejen češtiny) neuvědomují - a snad proto autor zvolil angličtinu(?).

Předložená kniha je přehledně členěna jak vertikálně (typem, velikostí i tloušt'kou písma), tak horizontálně (členění na oddíly a uvnitř oddílů na kapitoly a podkapitoly), a tím je text zřetelně hierarchizován, odlišován jazyk a metajazyk.
Na následujících rrádcích vyberu namátkou několik námětů, nad nimiž čtenáři př̌i studiu mohou dále přemýšlet:

Zvažovat hranici mezi hovorovostí a neutrálností jazykových prostředků - ta je pohyblivá. Obdobně i funkčně posuzovat odmítání pronikajících jevů (viz hromadění předložek nebo jejich vzájemné záměny, např̀. s. 36 a 37). Povšimnout si, že vztah mezi (číselnými) substantivy a číslovkami se v současné odborné literatuře posouvá, a nejen mezi nimi (viz vztah číslovek s př́slovci, zájmeny, adjektivy).

Co vedlo autora k stanovisku, že domácké podoby jmen jako Hančí, Máři, Anči nebo že lexém paní přiřazuje k substantivizovaným adjektivům, s. 51. (A vůbec proč v dané souvislosti mluví o lexému, jde o slovní tvar.) Samozřejmě jako v každé publikaci i zde bychom našli další místa, která vzbuzují rozpaky či alespoň otázky, ale to už ponecháme na čtenárích.

Publikace obsahuje kromě 23 odborných textů i další náležitosti, stručné anglické resumé a přehled autorovy publikační činnosti za léta 2016-2018. Čtenář by ocenil, kdyby ke knize byl přiložen (když už ne jmenný, tak) alespoň věcný rejstř́ik.

Než ukončím tuto recenzi, ještě bych chtěla vyjádřit své milé překvapení nad tím, co jsme od odborné knihy neočekávali, ale co ji náramně zlidštilo: Po stručném subjektivně zabarveném úvodu následuje kapitolka Dědeček, začínající kratičkou, milou básničkou:

Ted',

na prahu šedesátky. Postávám

před stárím vrátky.

Vstoupit nechci,

couvám zpátky -

život náš

je přec tak krátký!

S osudem

však nejsou hrátky..

a pokračuje rozkošným př́během o svém setkání s holčičkou a její maminkou v metru - oč šlo, si čtenáŕ domyslí z názvu kapitolky.

Po ní pak pokračuje osobním vyznáním Korejská stopa, inspirovaným pracovním, učitelským pobytem "na podmanivém, tajuplném a okouzlujícím Dálném východě".

Závěrem: Předkládaná práce shrnuje několikaleté autorovo úsilí a přesvědčuje o jeho píli a odborné erudici. Může obohatit čtenáře o mnohé zajímavé poznatky z bohemistiky a z jejího vyučování, zvláště jinojazyčného, dokonce obsahuje i vhodný výukový materiál využitelný př́mo ve výuce. A tak může být tato publikace i př́mým pomocníkem učitelů češtiny jako nemateřsko jazyka. 